\title{
ZMIANY UKŁADÓW WSPÓŁRZECDNYCH W PRAKTYCE GEODEZYJNEJ MIASTA ŁODZI
}

\begin{abstract}
W pracy omówiono układy współrzędnych prostokątnych miasta Łodzi, które były stosowane przy opracowaniach geodezyjno-kartograficznych. Omówiono zmiany układów współrzędnych oraz cele tych zmian wynikające z potrzeb rozwijającego się miasta, zmian w gospodarce krajowej i zmian w uregulowaniach prawnych. Dokonano analizy zmian, jakie wniosło wprowadzenie jednolitego dla całego kraju układu współrzędnych „2000”. Układ współrzędnych „2000” został wprowadzony w miejsce dotychczas stosowanych w Łodzi układów „ŁAM” i „1965”, poprzez dokonanie transformacji bazy numerycznej dla 215 obrębów geodezyjnych miasta Łodzi. Wśród nich 146 zawierało pełną treść ewidencji gruntów i budynków, natomiast 69 obrębów zawierało tylko dane dotyczące działek. Transformacji dokonano zgodnie z warunkami technicznymi na wykonanie konwersji map numerycznych obszaru miasta Łodzi. Szczegółowej analizy dokonano dla obiektów ewidencyjnych, którymi są działki. Dokonano analizy zmian powierzchni działek dla wybranych obrębów geodezyjnych, jakie wniosło wprowadzenie układu współrzędnych ,2000” i stwierdzono, że na 883 działkach nastąpił przyrost powierzchni a na 115 działkach powierzchnia uległa zmniejszeniu. Zmiany te zostały wprowadzone do Ewidencji Gruntów, Budynków i Lokali prowadzonej dla miasta Łodzi dla analizowanych obrębów geodezyjnych.

Jest to pierwszy artykuł obejmujący analizę zmian powierzchni miasta Łodzi wynikającej ze zmiany układów współrzędnych. Z przeprowadzonej analizy wynika, iż powierzchnia miasta zwiększyła się. Wprowadzenie układu współrzędnych prostokątnych ,2000” dla miasta Łodzi spowodowało ujednolicenie wykonywanych opracowań geodezyjnych.
\end{abstract}

Słowa kluczowe: układy, transformacja, działka, powierzchnia

\section{Wprowadzenie}

Miasto Łódź prawa miejskie otrzymało w lipcu 1423 r., z chwilą podpisania przez Króla Władysława Jagiełło przywileju lokacyjnego miasta z jego dzisiejszą nazwą. Jednak o rozwoju Łodzi możemy mówić dopiero w XIX wieku.

W 1821 roku podjęto decyzję o założeniu na południe od Starego Miasta Osady Sukienniczej. Projekt rozplanowania osady, częściowo na gruntach oby-

\footnotetext{
${ }^{1}$ Anna Białecka, Politechnika Łódzka, Wydział Budownictwa, Architektury i Inżynierii Środowiska, Al. Politechniki 6, 90-924 Łódź, 501617950, anna.bialecka@p.lodz.pl
} 
wateli, proboszcza i w części na gruntach rządowych, został wykonany na zlecenie Rajmunda Rembielińskiego Prezesa Komisji Województwa Mazowieckiego, działającego w imieniu Rządu Królestwa Polskiego [1]. Dla ostatecznego uregulowania Osady Sukienniczej, Rajmund Rembieliński wydał dla geometry instrukcję, datowaną na 12 czerwca 1823 r. [1].

Zalecenia instrukcji geometra Filip de Viebig wykonał w tymże 1823 r., sporządzając „Plan Sytuacyjny, uregulowanych ogrodów sukienniczych, Mieście Łodzi położonego, w obwodzie Łęczyckim Województwie Mazowieckim”. Wyznaczył on ponad 200 placów budowlanych i Rynek Nowego Miasta (obecnie plac Wolności), ośmioboczny plac usytuowany w osi traktu Piotrkowskiego [3].

Wymieniony plan został sporządzony w skali 1:5000, według „Miary Warszawskiey, rachując 50 prętów na call dziesiętny" - zgodnie z opisem na planie [1]. Plan ten jest opracowaniem jednostkowym, zorientowanym generalnie na północ, ale ściśle z kierunkiem osi Traktu od Piotrkowa - dzisiejszej ulicy Piotrkowskiej.

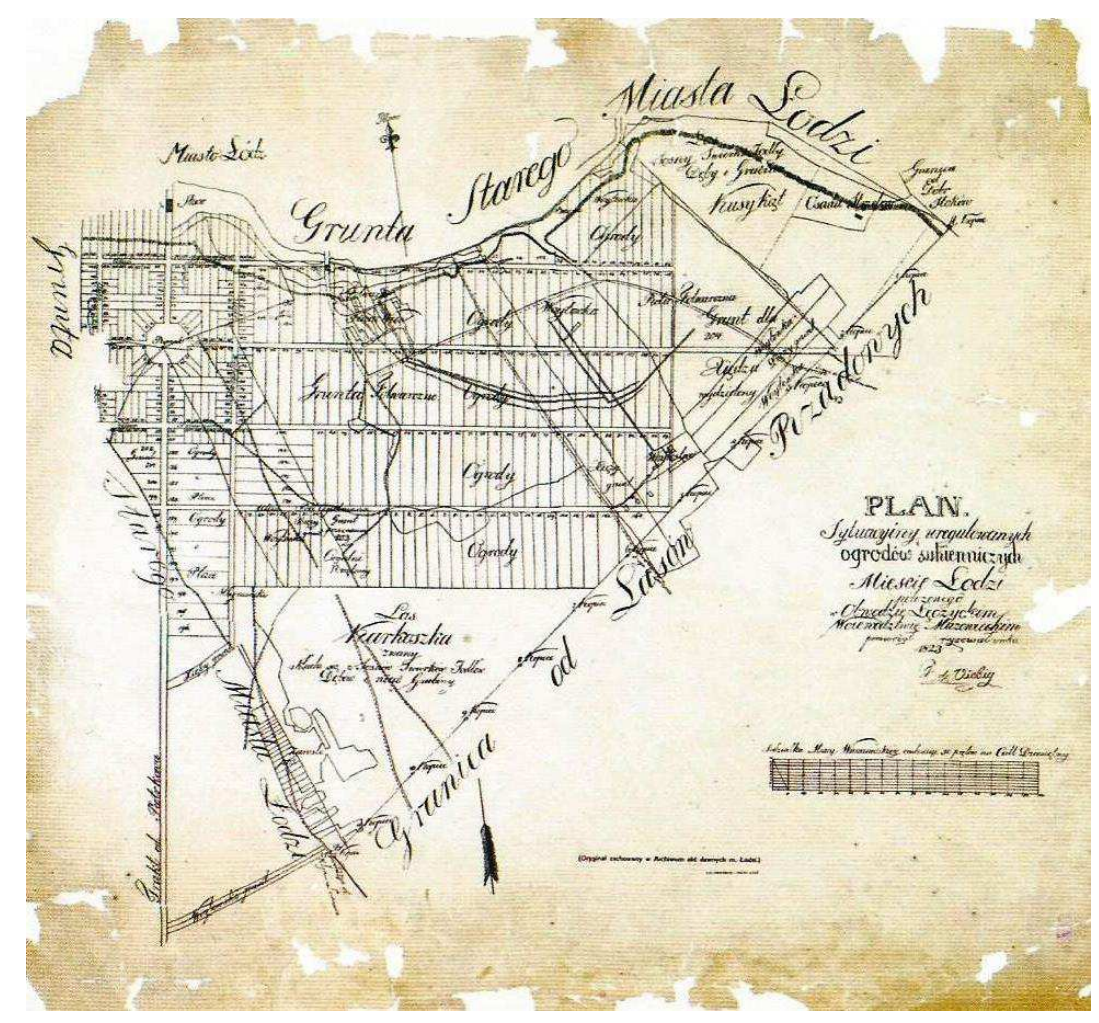

Rys. 1. Plan sytuacyjny sporządzony przez geometrę Filipa de Viebiga w 1823 r., zbiory kartograficzne APŁ nr 517a, na podstawie [3]

Fig. 1. Situation plan drawn up by geometer Filipa de Viebiga w 1823 r., cartographic APŁ nr 517a, based on [3] 
Wykonywane wówczas mapy i plany regulacyjne sporządzane były, jako mapy jednostkowe, każda na jednym arkuszu, według miary obowiązującej w danym czasie na tym obszarze. Mapy powstawały na podstawie pomiaru w terenie, w nawiązaniu do istniejących kopców granicznych oraz punktów przecięć ulic. Kierunkiem orientującym prawie zawsze był kierunek osi ulicy Piotrkowskiej.

W ciągu bardzo krótkiego okresu czasu, w tempie, którego nie zna żadne większe miasto Europy, rosła liczba mieszkańców miasta [1]. Zmieniała się również powierzchnia miasta w wyniku przyłączania terenów sąsiednich.

Tabela 1. Zmiana liczby mieszkańców i powierzchni Łodzi w latach 1821-1915

Table 1. Changing the number of inhabitants and the surface of Lodz in the years 1821-1915

\begin{tabular}{|r|r|c|}
\hline Rok & Liczba mieszkańców & Powierzchnia $\mathbf{~ k m}^{\mathbf{2}}$ \\
\hline 1821 & 799 & 12,6 \\
\hline 1840 & 20000 & 27,4 \\
\hline 1872 & 50000 & 27,4 \\
\hline 1897 & 315000 & 27,4 \\
\hline 1915 & Około 600000 & 58,8 \\
\hline
\end{tabular}

W latach 1894-1896 zostaje sporządzone wielkoskalowe opracowanie geodezyjno-kartograficzne, w skali 1:1680, dla całego miasta Łodzi. Dla opracowania przyjęto lokalny układ współrzędnych prostokątnych: oś X skierowana była na północ i pokrywała się z południkiem ,rzeczywistym” (jak opisano na arkuszu tytułowym mapy), a oś Y skierowana była na wschód. Układ lokalny został przyjęty tak, aby cały obszar miasta $\mathrm{w}$ granicach administracyjnych znalazł się w I ćwiartce; oznaczono również deklinację magnetyczną. W opracowaniu podano również powierzchnię nieruchomości wyrażoną w dziesiatinach i sążeniach kwadratowych.

W styczniu 1918 r. Magistrat miasta Łodzi podjął zdecydowane działania zmierzające do przygotowania prac związanych z budową wodociągów i kanalizacji. Do opracowania szczegółowych projektów potrzebne były przede wszystkim dokładne mapy sytuacyjno-wysokościowe w skali 1:250, opracowane na podstawie bezpośrednich pomiarów, opartych na poziomej i wysokościowej osnowie geodezyjnej. W związku z tym Rada Miejska podjęła uchwałę o utworzeniu w magistracie Oddziału Pomiarów.

Oddział Pomiarów rozpoczął działalność 1 lipca 1918r. Do zakresu jego prac wchodziło [2]:

1) założenie lokalnej sieci triangulacyjnej,

2) założenie sieci niwelacji trygonometrycznej,

3) założenie sieci poligonometrycznej,

4) obliczenie i wyrównanie opisanych w punktach 1) i 2) pomiarów metodą najmniejszych kwadratów,

5) pomiar szczegółów terenowych, 
6) niwelacja techniczna,

7) opracowanie mapy poszczególnych kwartałów miasta w skali 1:250.

Łódzka sieć triangulacyjna była siecią lokalną. Jako początek układu współrzędnych $\mathrm{X}=0,00 \mathrm{~m}$ oraz $\mathrm{Y}=0,00 \mathrm{~m}$ przyjęto punkt centralny tej sieci krzyż na wieży Kościoła św. Krzyża, przy zbiegu ulic Przejazd (obecnie Tuwima) i Sienkiewicza. Oś X lokalnego układu współrzędnych prostokątnych pokrywała się z południkiem geograficznym, a oś Y skierowana była na wschód. Orientacja sieci według południka geograficznego została dokonana na podstawie pomiarów astronomiczno-geodezyjnych wykonanych przez prof. Tadeusza Banachiewicza w 1921r.

Wszystkie pomiary zostały sporządzone w systemie metrycznym, zgodnie z „Dekretem o miarach” z dnia 8 lutego 1919r., będącym jednym z pierwszych aktów ustawodawczych niepodległej Polski. Dekret likwidował wszystkie poprzednie systemy miar, również odziedziczone po zaborcach.

Założona sieć poligonometryczna stanowiła podstawę do pomiarów terenowych, które były sukcesywnie przenoszone na papier kreślarski. W ten sposób powstały mapy sytuacyjne poszczególnych kwartałów ulic, jako mapy jednostkowe, tzw. „bloki”. Były one sporządzane w skali 1:250, 1:500 lub 1:1000, w zależności od stopnia zagęszczenia terenu. Zawierały w swej treści szczegóły terenowe, miary wynikające $\mathrm{z}$ pomiarów oraz numery porządkowe, numery hipoteczne nieruchomości i nazwiska władających, które dały się ustalić w trakcie prac polowych. Przykład „bloku” pokazano na rys. 2.

Mapy te zostały wykorzystane do opracowania szczegółowych projektów wykonawczych dla zakładanej wówczas ogólnomiejskiej sieci wodociągowej i ka-

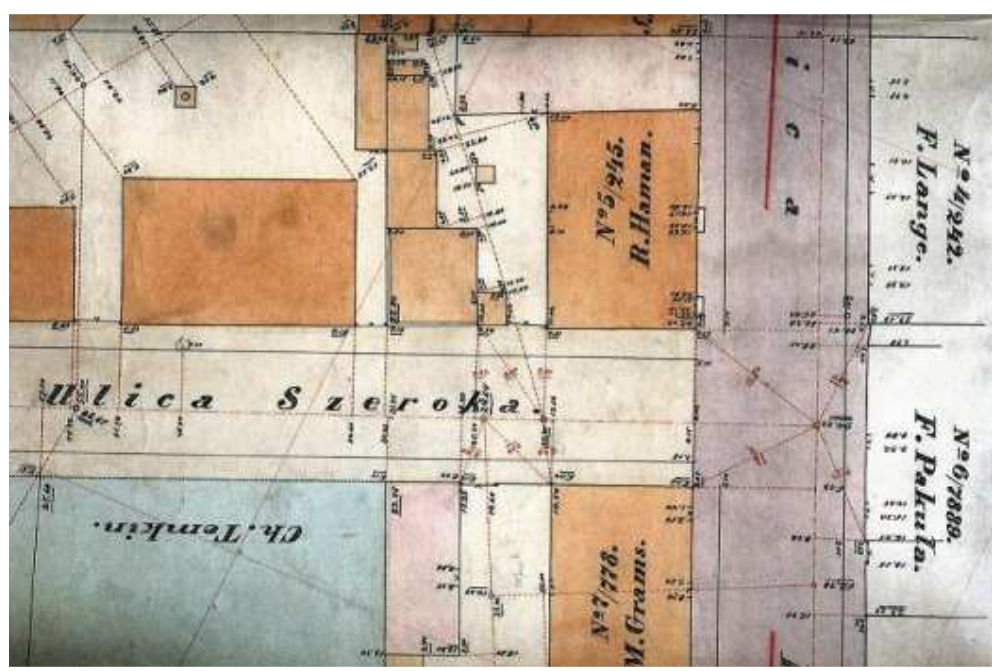

Rys. 2. Fragment „bloku” (skala 1:250), na podstawie [1]

Fig. 2. Fragment „block” (scale 1:250), based on [1] 
nalizacyjnej oraz stanowiły podstawę do sporządzenia innych map tematycznych dla potrzeb służb miejskich (np. mapy ulic, sporządzane dla potrzeb nadawania numeracji porządkowej posesjom) [1].

\section{Układy współrzędnych miasta Łodzi}

\subsection{Lokalny układ współrzędnych ,ŁAM”}

Na początku lat 30-tych XX wieku zmieniły się wymagania techniczne narzucone dużym miastom przez władze państwowe. Zmiany te miały na celu ujednolicenie prac geodezyjnych i zwiększenie dokładności pomiarów oraz powiązanie sieci lokalnych $\mathrm{z}$ osnową zakładaną dla całego kraju [2]. Zaistniała więc w Łodzi potrzeba dokonania nowych pomiarów założonej lokalnej sieci triangulacyjnej. Potrzeba ta była tym bardziej pilna, że w sieci założonej w latach 19181921 było wiele zniszczeń. Projekt zagęszczenia miejskiej sieci triangulacyjnej został sporządzony w Oddziale Pomiarów łódzkiego magistratu w 1932 r. i zatwierdzony w Ministerstwie Spraw Wewnętrznych w dniu 24 kwietnia 1933 r. Jednak zatwierdzony projekt podlegał jeszcze zmianom. Koniecznym było rozszerzenie sieci i dostosowanie jej do zakładanej na zlecenie Urzędu Wojewódzkiego Łódzkiego siatki triangulacyjnej Małego Regionu Łódzkiego [2].

Po wykonaniu pomiarów podstawowych dokonano powtórnych obliczeń miejskiej sieci triangulacyjnej. Orientację sieci wg południka geograficznego przyjęto z obliczeń sieci triangulacyjnej wykonanych w latach 1918-1921. Istotna zmiana, jaka została wówczas wprowadzona, dotyczyła punktu przyłożenia sieci. Współrzędne centralnego punktu sieci triangulacyjnej - na Kościele Św. Krzyża - uzyskały wartości $X=50000,00 \mathrm{~m}, \mathrm{Y}=50$ 000,00 m. Skierowanie osi układu pozostało niezmienione. Zlikwidowano w ten sposób ujemne wartości współrzędnych X i Y, które zwiększały ryzyko pomyłek.

W 1935 r. podjęto decyzję o założeniu nowej jednolitej dla całego miasta mapy sytuacyjno-wysokościowej, w skali 1:1000, w kroju sekcyjnym. Przy opracowywaniu tej mapy nie prowadzono żadnych ustaleń stanów prawnych nieruchomości. Była ona używana na potrzeby miasta do połowy lat 1970-tych.

W latach 60-tych, w ramach ogólnokrajowego projektu budowy jednolitej, nowoczesnej osnowy geodezyjnej, wykonano pomiary również dla miasta Łodzi. Nowa sieć triangulacyjna, dla obszaru centralnej części miasta, w znacznej mierze pokryła się ze starą, założoną w latach 1930-1935.

W wyniku nowych pomiarów i obliczeń, współrzędne punktów sieci triangulacyjnej uległy niewielkim zmianom. Otrzymany w ten sposób układ współrzędnych otrzymał nazwę „Układ ŁAM” (ŁAM - Łódzka Aglomeracja Miejska).

Lokalny układ obowiązywał dla wykonywanych prac geodezyjnych do dnia 20.07.2009 r., gdy został wprowadzony, jako obowiązujący dla miasta Łodzi układ współrzędnych ,2000”. 
W latach 1970-tych przystąpiono również do opracowania jednolitej dla całego miasta mapy sytuacyjno-wysokościowej, w skali 1:500, w kroju sekcyjnym. Podstawę do jej opracowania stanowiły arkusze mapy założonej w latach 30-tych.

W latach 1958-1966 została założona w mieście Łodzi ewidencja gruntów i budynków. Zawierała ona część kartograficzną, czyli mapę ewidencyjną i jej matrycę oraz część opisową w postaci rejestrów - „stara ewidencja”. Każda dzielnica miasta stanowiła odrębną jednostkę ewidencyjną podzieloną na 930 obrębów.

W latach 1971-1981 założono nową ewidencję gruntów i budynków, zgodnie z Zarządzeniem Ministrów Rolnictwa i Gospodarki Komunalnej z dnia 20 lutego 1969 r.. Zachowano podział na jednostki ewidencyjne, ale zmianie uległ podział na obręby. W ,nowej ewidencji gruntów i budynków” utworzono 188 obrębów. Ewidencja składała się również z części kartograficznej i części opisowej. Część kartograficzną stanowiła, prowadzona ręcznie mapa ewidencyjna w skali 1:1000 oraz zarysy pomiarowe granic, prowadzone w formie szkicu w przybliżonej skali. Część opisową stanowił rejestr gruntów i skorowidze prowadzone manualnie.

W 1990 r. dla celów prowadzenia części opisowej ewidencji gruntów wprowadzono program komputerowy, który usprawnił prowadzenie rejestru gruntów i wprowadzanie zmian.

\subsection{Układ współrzędnych ,1965”}

Miasto Łódź, w czasie swojego szybkiego rozwoju, powiększało się kilkakrotnie o tereny przyległe. Ostatnia inkorporacja przyległych do Łodzi terenów nastąpiła z dniem 1 stycznia 1988 r. i wyniosła 7890 ha [3]. W jej wyniku powierzchnia miasta powiększyła swój obszar do 29325 ha [3].

Przyłączone tereny pochodziły:

- z gmin - Aleksandrów Łódzki, Stryków, Zgierz, Brójce, Pabianice, Rzgów, Andrespol, Nowosolna,

- z miasta Konstantynów Łódzki.

Dla przyłączonych terenów opracowania geodezyjne były prowadzone w układzie „1965”, w skali 1:1000 i 1:2000.

Ewidencja gruntów i budynków na terenach przyłączonych, składająca się z części kartograficznej i części opisowej, prowadzona była w sposób tradycyjny.

Wprowadzony w 1990 r. program komputerowy dla części opisowej ewidencji gruntów objął również obszar przyłączony do miasta.

Dla prac geodezyjnych wykonywanych na terenach przyłączonych do miasta, układ współrzędnych „1965” obowiązywał do dnia 20.07.2009 r, gdy został wprowadzony, jako obowiązujący dla miasta Łodzi, układ współrzędnych „2000”. 


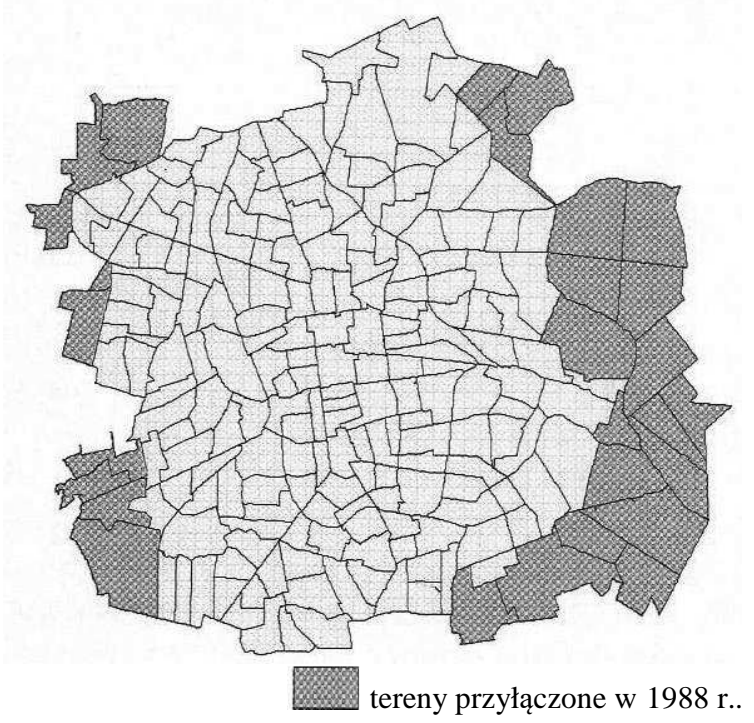

Rys. 3. Lokalizacja terenów przyłączonych do miasta Łodzi w 1988 r.

Fig. 3. Location of sites connected to the city of Lodz in 1988

\subsection{Układ współrzędnych ,2000”}

Modernizację ewidencji gruntów i budynków oraz sporządzenie mapy zasadniczej miasta Łodzi w formie elektronicznej rozpoczęto w latach 90-tych dla dzielnicy Śródmieście.

Jednak kompleksowe działania rozpoczęto w 2001 r., gdy przystąpiono do założenia ewidencji lokali oraz modernizacji ewidencji gruntów i budynków na obszarze miasta Łodzi.

Celem wszczętego postępowania było:

1) korygowanie granic nieruchomości,

2) ujednolicenie ewidencji ze stanem faktycznym i zapisami w księgach wieczystych, 3) pełna informatyzacja ewidencji.

Równocześnie prowadzono prace związane z założeniem mapy numerycznej będącej przekształceniem analogowej mapy zasadniczej.

Działania te były finansowane $\mathrm{z}$ budżetu miasta Łodzi, ale również zostały pozyskane środki unijne w ramach projektu „System Informacji o Terenie dla miasta Łodzi”.

Celem głównym podjętych działań było szybkie udostępnianie wiarygodnej informacji o przestrzeni miasta jego mieszkańcom, przedsiębiorcom, inwestorom zewnętrznym i urzędom. Szybkie udostępnianie informacji jest możliwe przy wykorzystaniu nowoczesnych środków informatycznych.

Całość prac została wykonana w aplikacjach:

1) EGBiL - ewidencja gruntów, budynków i lokali, 
2) Geo-Info V - numeryczna mapa zasadnicza, jako zintegrowany System Informacji Przestrzennej, w którym wszystkie dane geometryczne i opisowe gromadzone są w jednej relacyjnej bazie danych.

Wprowadzenie układu współrzędnych „2000” z dniem 20.07.2009 r, zostało dokonane dla całego miasta w zakresie ewidencji gruntów i budynków oraz w części miasta dla mapy zasadniczej.

W lipcu 2009 r. wykonano transformację bazy numerycznej dla 215 obrębów m. Łodzi. Wśród nich 146 zawierało pełną treść ewidencji gruntów i budynków, natomiast 69 obrębów zawierało tylko dane dotyczące działek. Transformacji dokonano zgodnie $\mathrm{z}$ warunkami technicznymi na wykonanie konwersji (transformacji) map numerycznych obszaru miasta Łodzi z układu lokalnego „,ŁAM” do układu „2000/18”, opracowanymi przez firmę ALGORES-SOFT z siedzibą w Rzeszowie.

Algorytm transformacji pojedynczego punktu uwzględniał dwa kroki obliczeniowe:

1) przekształcenie zasadnicze, według ustalonego wielomianu określającego generalny związek transformacyjny między układami „ŁAM” i ,2000/18”,

2) korekta posttransformacyjna Hausbrandta, eliminująca lokalne deformacje układu pierwotnego nieobjęte przekształceniem zasadniczym.

Transformacji dokonano z kontrolą aplikacji, która miała na celu:

1) obliczenie odchyłek transformacji dla wszystkich punktów dostosowania,

2) sprawdzenie, czy w zasadniczym etapie transformacji przekształcenie ŁAM=>2000/18 i odwrotne 2000/18=>ŁAM prowadzi dokładnie do współ-

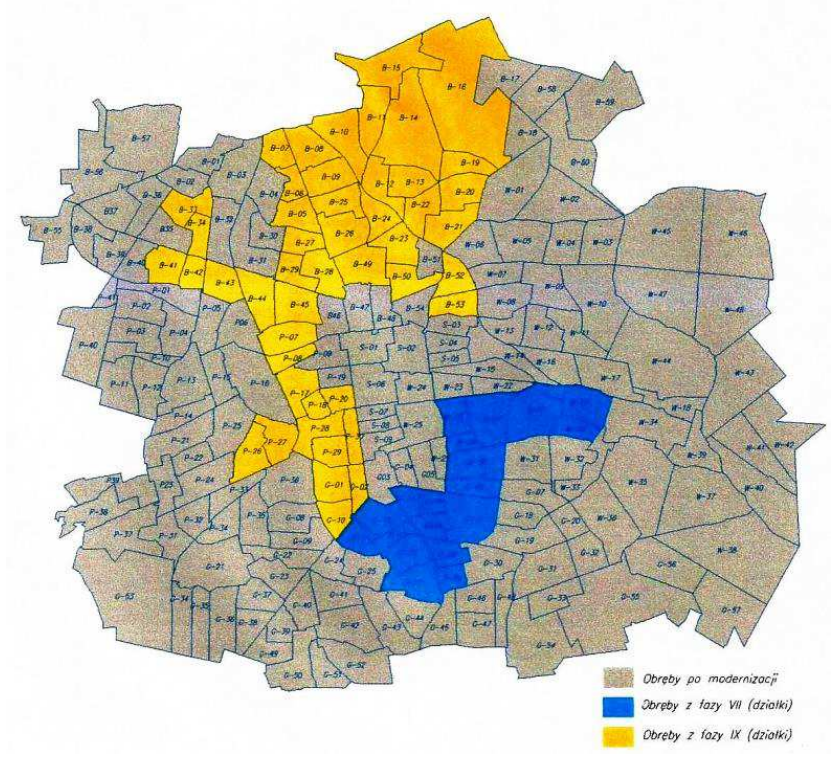

Rys. 4. Szkic podziału miasta na obręby geodezyjne

Fig. 4. Sketch division of the city for surveying districts 
rzędnych wejściowych w układzie ŁAM (z dokładnością do błędu zaokrąglenia współrzędnych).

Wykonano również kontrolę ilościową i jakościową obiektów ewidencyjnych przed i po transformacji - działki ewidencyjne i budynki.

3. Analiza zmian powierzchni gruntów w wybranych obrębach geodezyjnych miasta Lodzi, powstała w wyniku transformacji z układu ,LAM” na układ „2000”

Do szczegółowej analizy wybrano 8 obrębów zlokalizowanych w dzielnicy Widzew - położonych na terenach, gdzie obowiązywał układ współrzędnych „ŁAM” i układ „1965” [4, 5]. Obręby te pokazano na rysunkach nr 5 i 6.

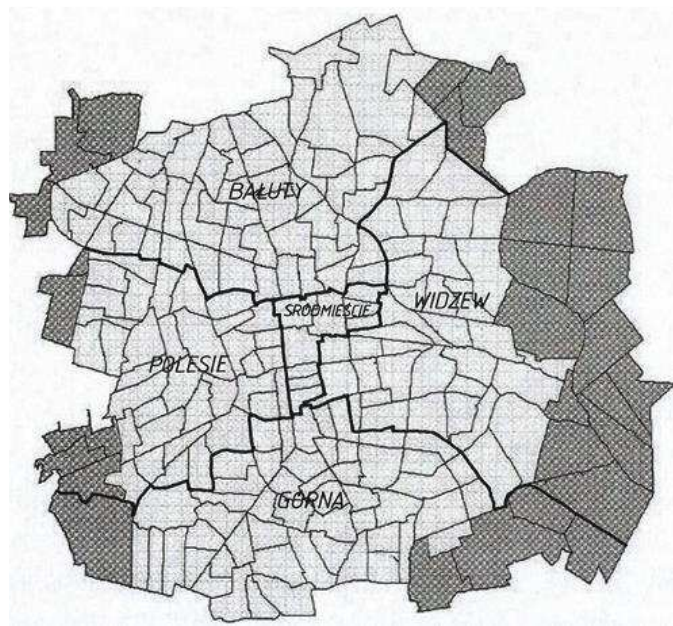

Rys. 5. Szkic podziału miasta na dzielnice

Fig. 5. Sketch division of the city into districts

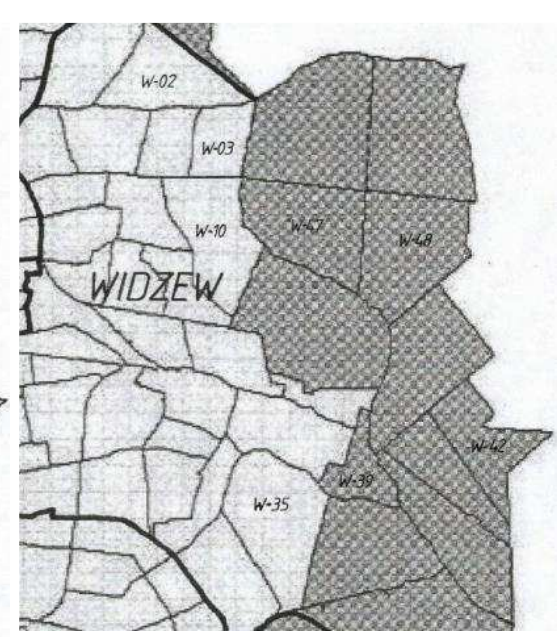

Rys. 6. Szkic fragmentu dzielnicy Widzew z oznaczeniem wybranych obrębów geodezyjnych

Fig. 6. Sketch portion of the district Widzew with the designation of selected surveying districts

Na rysunkach $7 \div 10$ przedstawiono analizę zmian w powierzchni dla wybranych obrębów geodezyjnych. 

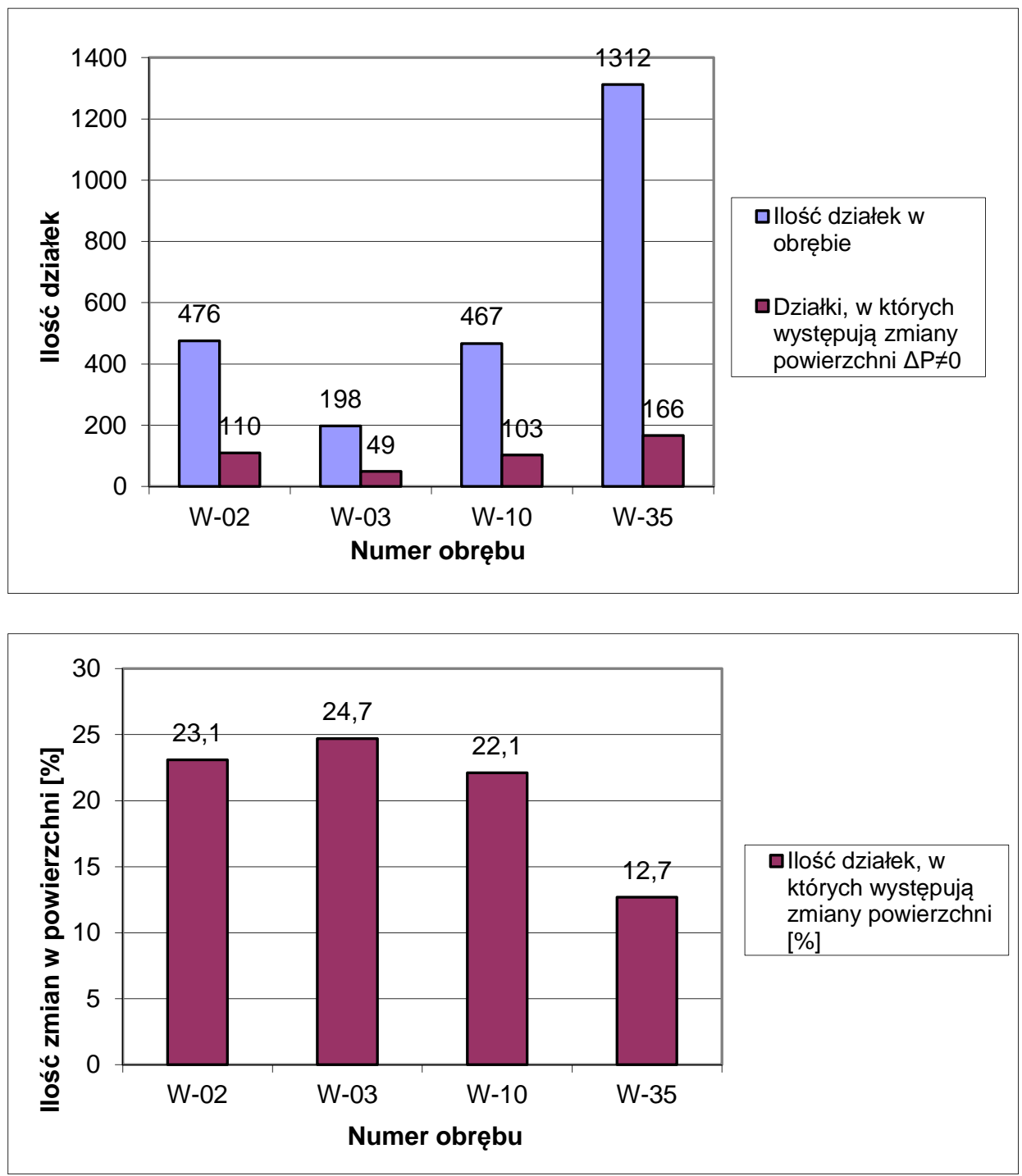

Rys. 7. Analiza zmian w powierzchni działek dla obrębów geodezyjnych, dla których dotychczas obowiązywał układ współrzędnych „ŁAM”

Fig. 7. Analysis of changes in land areas for surveying districts, which previously force the coordinate system "LAM" 

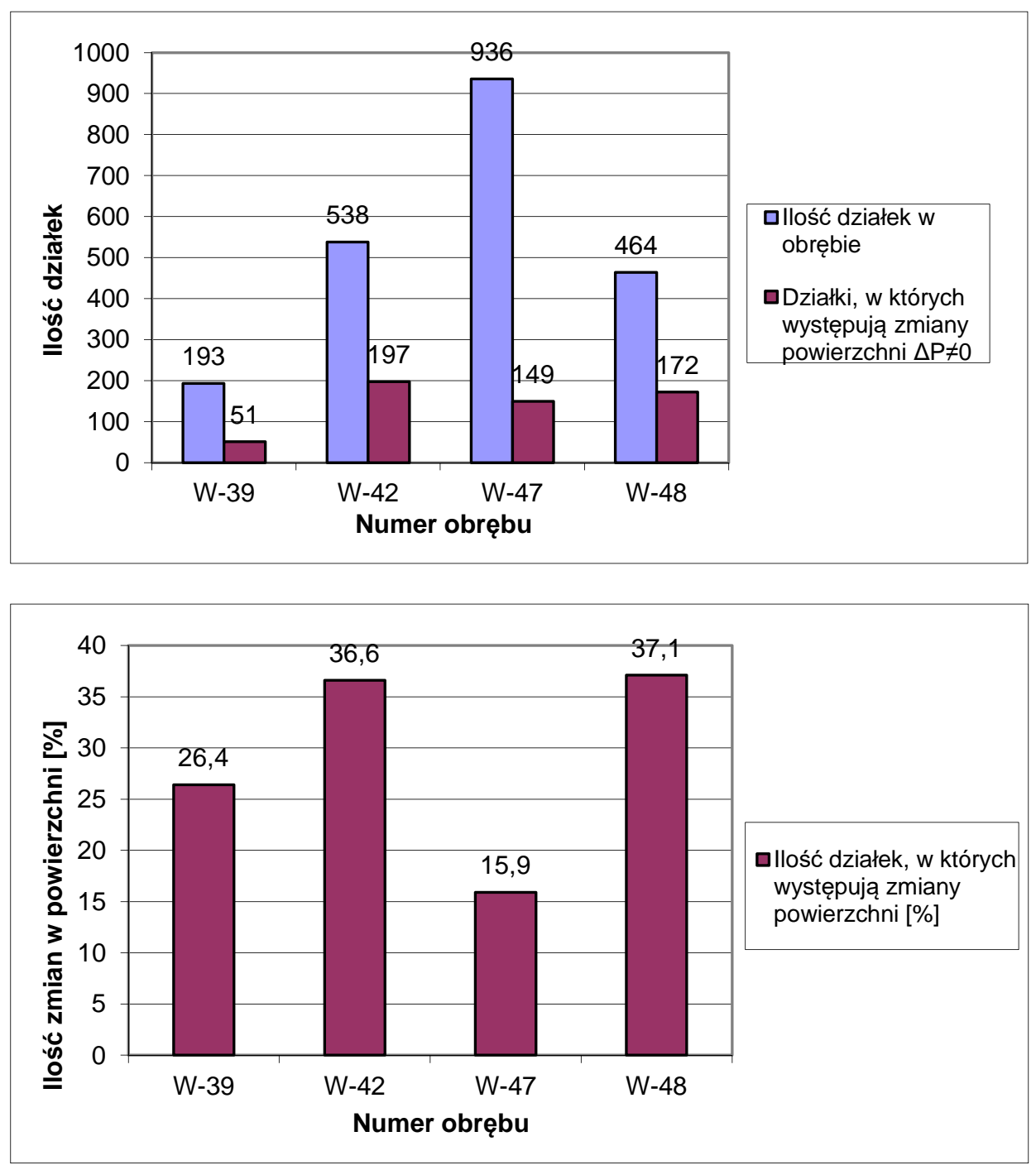

Rys. 8. Analiza zmian w powierzchni działek dla obrębów geodezyjnych, dla których dotychczas obowiązywał układ współrzędnych „1965”

Fig. 8. Analysis of changes in land areas for surveying districts, which previously force the coordinate system "1965" 


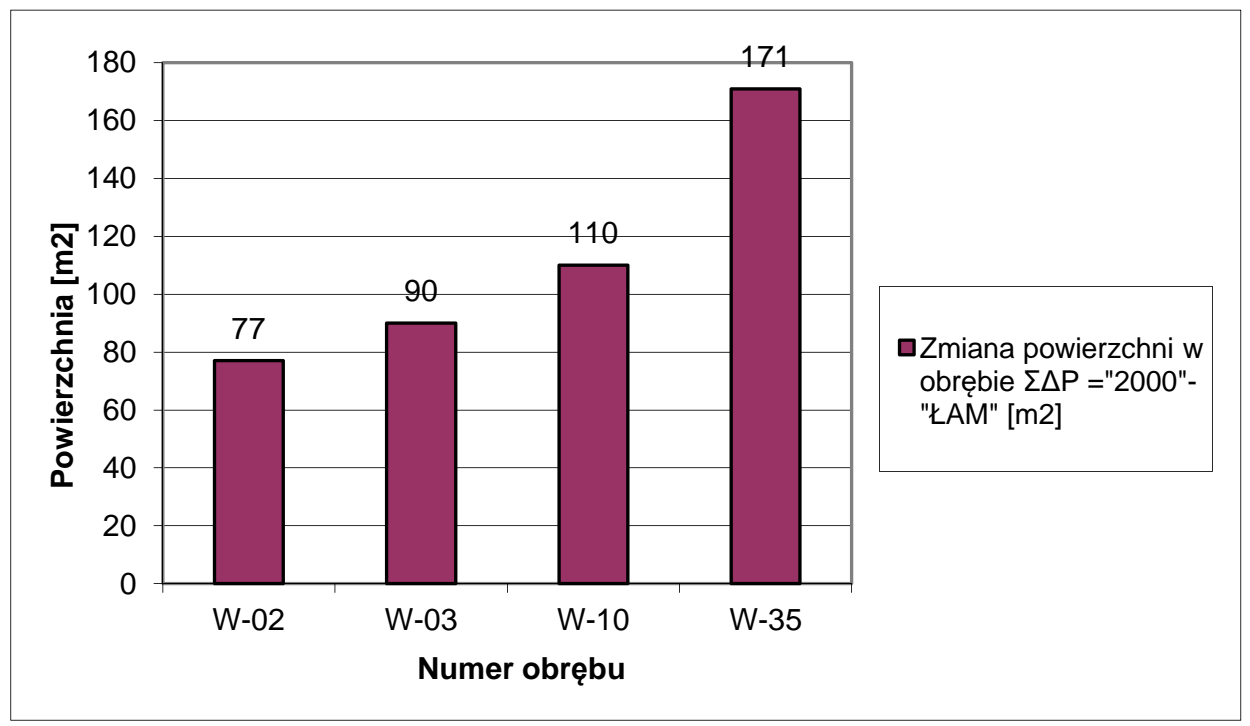

Rys. 9. Analiza wielkości zmian w powierzchni dla wybranych obrębów geodezyjnych - dotychczasowy układ współrzędnych "EAM"

Fig. 9. Analysis of change the size of the surface at selected districts surveying - the current coordinate system "LAM"

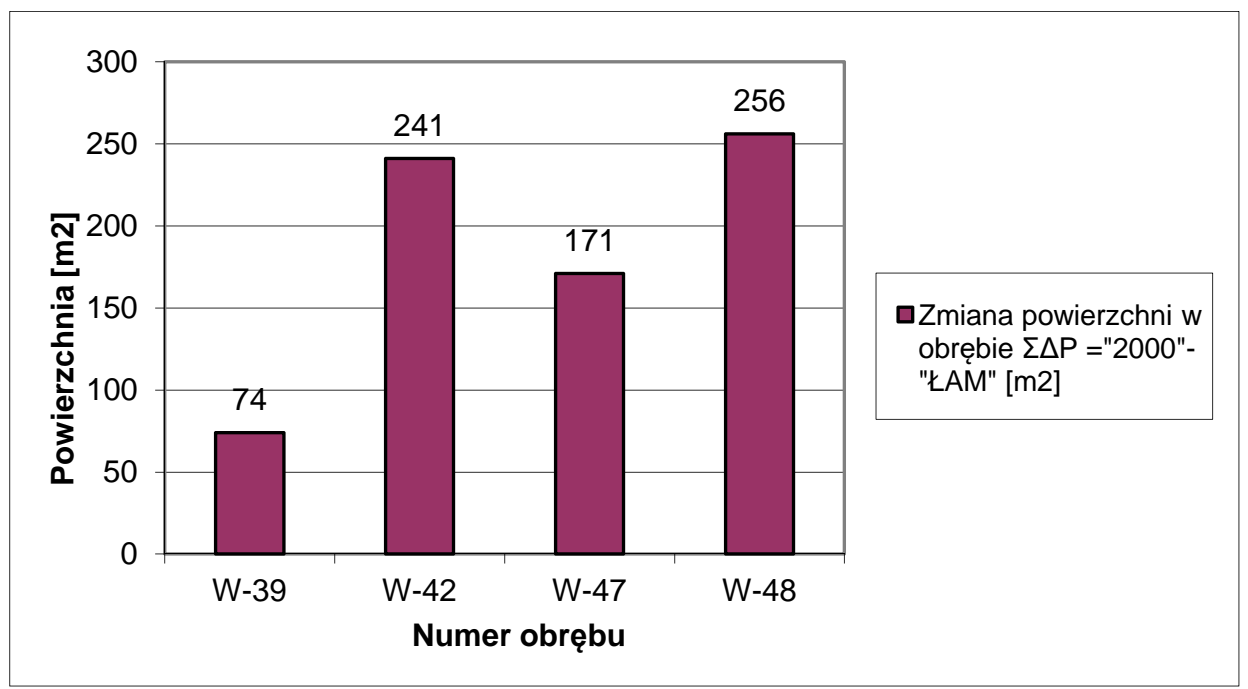

Rys. 10. Analiza wielkości zmian w powierzchni dla wybranych obrębów geodezyjnych - dotychczasowy układ współrzędnych "1965"

Fig. 10. Analysis of change the size of the surface at selected districts surveying - the current coordinate system "1965" 
Rysunki $11 \div 13$ przedstawiają analizę ilościową w powierzchni działek, z uwzględnieniem wielkości zmian.
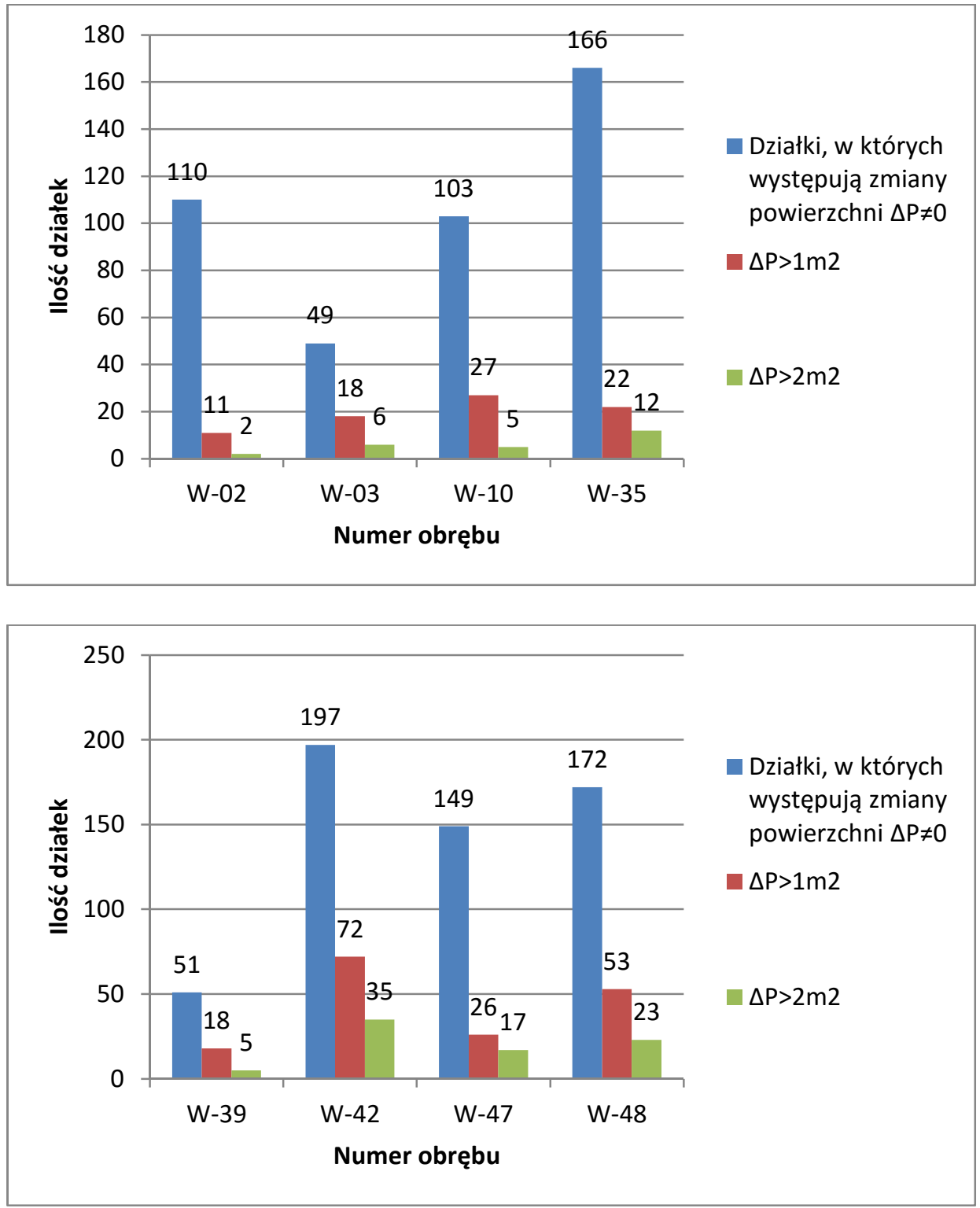

Rys. 11. Analiza ilościowa zmian w powierzchni, z uwzględnieniem wielkości zmiany

Fig. 11. Quantitative analysis of changes in the surface, taking account of changes 


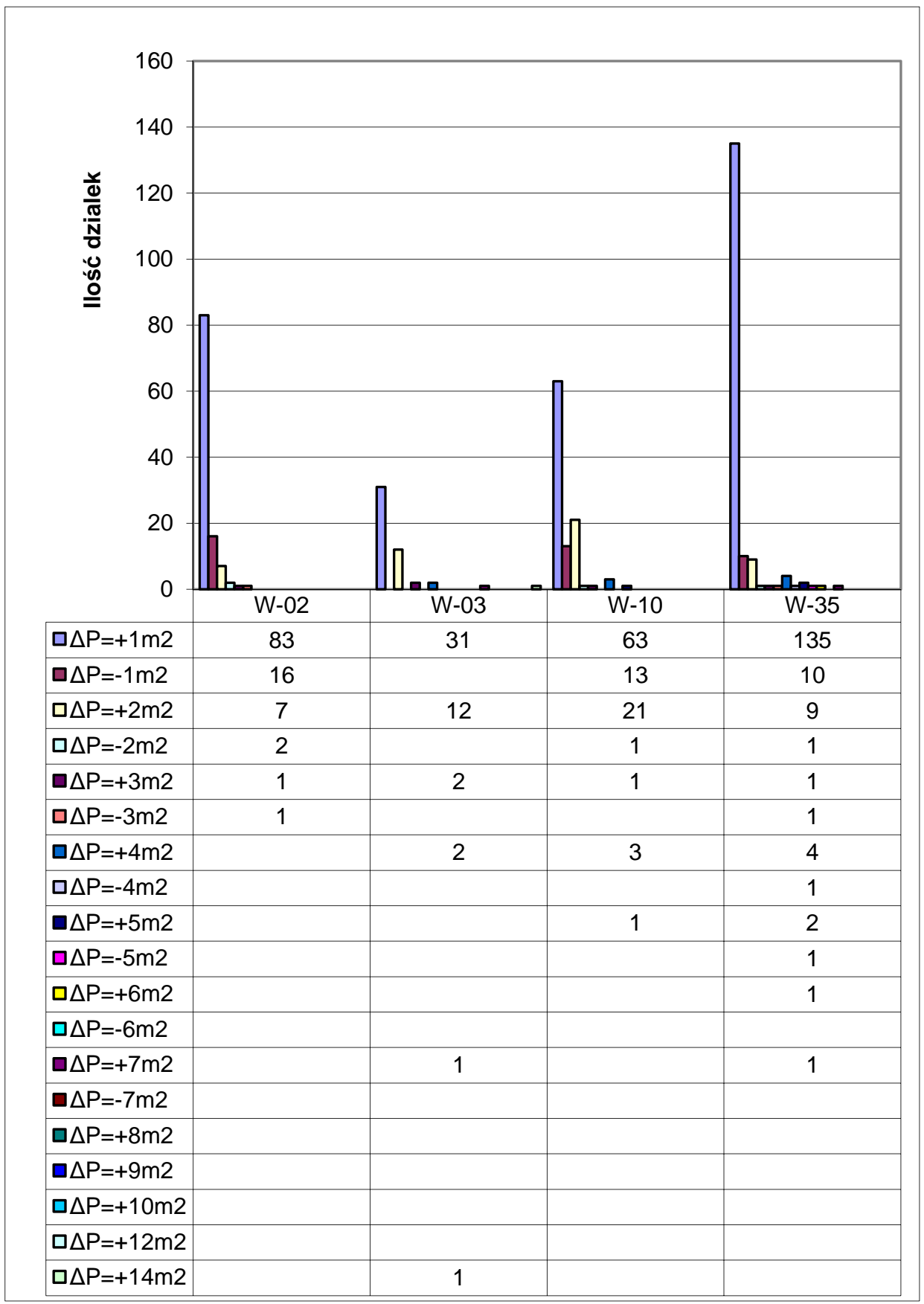

Rys. 12. Zestawienie wszystkich zmian w powierzchni dla wybranych obrębów geodezyjnych

Fig. 12. A list of all the changes in the surface at selected districts surveying 


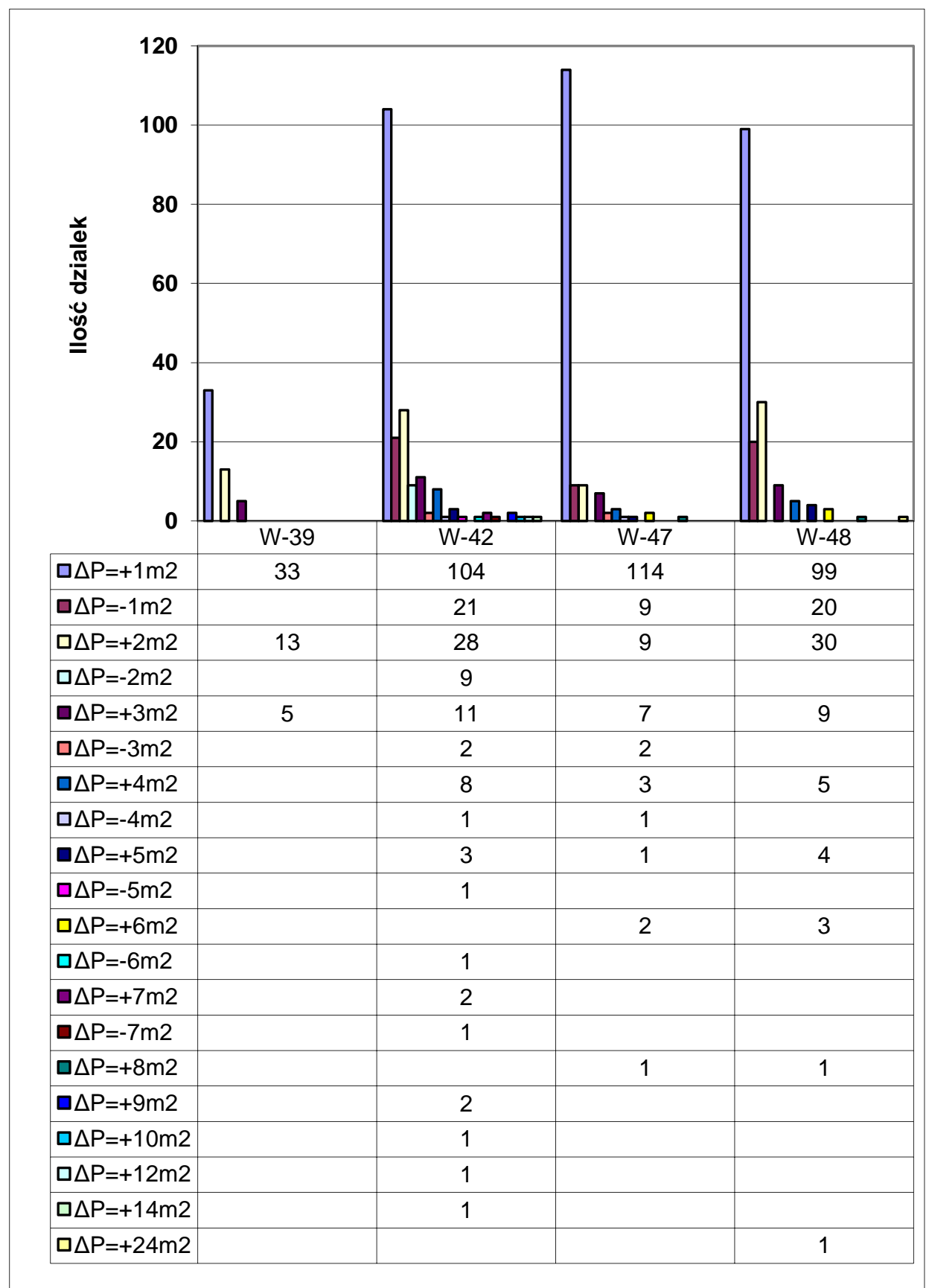

Rys. 13. Zestawienie wszystkich zmian w powierzchni dla wybranych obrębów geodezyjnych

Fig. 13. A list of all the changes in the surface at selected districts surveying 
Na podstawie przedstawionej analizy i wykresów stwierdzono, że na 883 działkach nastąpił przyrost powierzchni a na 115 działkach powierzchnia uległa zmniejszeniu. Zmiany te zostały wprowadzone do Ewidencji Gruntów, Budynków i Lokali prowadzonej dla miasta Łodzi dla analizowanych obrębów geodezyjnych.

Jest to pierwszy artykuł obejmujący analizę zmian powierzchni miasta Łodzi wynikającej ze zmiany układów współrzędnych. Z przeprowadzonej analizy wynika, iż powierzchnia miasta zwiększyła się.

Podobne analizy były wykonywane dla Krakowa [6]. Powierzchnia miasta po dokonaniu transformacji z układu współrzędnych „1965” na układ „2000” uległa zmniejszeniu.

\section{Wnioski}

Wprowadzenie układu współrzędnych prostokątnych „2000” dla miasta Łodzi spowodowało ujednolicenie wykonywanych opracowań geodezyjnych. Dla terenów położonych na styku dawnych układów „ŁAM” i „1965” została opracowana mapa numeryczna w jednolitym układzie współrzędnych prostokątnych.

Z przeprowadzonej analizy zmian powierzchni działek, dla których dokonano transformacji układów współrzędnych „ŁAM” i „1965” na układ „2000”, w poszczególnych obrębach geodezyjnych wynika, że:

1) powierzchnia działek w większości analizowanych przypadków wzrosła,

2) powierzchnia wszystkich analizowanych obrębów geodezyjnych zwiększyła się,

3) większe różnice w powierzchni wystąpiły dla obrębów, dla których dotychczas obowiązywał układ współrzędnych „1965”,

4) ilość zmian w powierzchni działek jest większa dla obrębów, dla których dotychczas obowiązywał układ współrzędnych „1965”,

5) przeważają zmiany powierzchni o wielkości $\pm 1 \mathrm{~m}^{2}$.

\section{Literatura}

[1] Czochański M., Kośka T., Kowalski G.: Zarys dziejów geodezji w Łodzi, Monografie Politechniki Łódzkiej, Łódź 2009.

[2] Szambelan Z.: Pomiary miasta Łodzi w latach 1918-1939, część I Lokalna triangulacja, Geodeta Magazyn Geoinformacyjny nr 4(155), kwiecień 2008.

[3] Rozwój terytorialny Łodzi, Urząd Miasta Łodzi, Biuro Informacji i Komunikacji Społecznej, Łódź 2010.

[4] Materiały archiwalne Łódzkiego Ośrodka Geodezji: Operat geodezyjno-prawny część I - Założenie mapy numerycznej, przeliczenie układu „ŁAM” na układ „2000”, przeliczenie wstępne. 
[5] Materiały archiwalne Łódzkiego Ośrodka Geodezji: Operat geodezyjno-prawny Przeliczenie układu „ŁAM” na układ „2000”, ewidencja gruntów i budynków.

[6] Banasiak P., Bagnicki J.: Kraj większy, Kraków mniejszy, Geodeta Magazyn Geoinformacyjny nr 3(178), marzec 2010.

\section{CHANGES OF COORDINATE SYSTEMS IN THE PRACTICE OF SURVEYING THE CITY OF LODZ}

\section{S u m m a r y}

The paper discusses the rectangular coordinate systems of the city of Lodz, which were used in studies of geodetic and cartographic data. The changes of coordinate systems and their objectives of these changes as a result of the growing needs of the city were discussed, as well as the changes in the domestic economy and in legal regulations. An analysis of the changes that brought the introduction of a uniform for the whole country coordinate system "2000" was conducted.

The coordinate system "2000" was introduced in place of previously used in Lodz systems "Lam" and "1965", by making the transformation of the numerical base for 215 surveying districts of the city of Lodz. Among them, 146 contain the full content of the register of land and buildings, while 69 concessions contained only data plots. The transformation was made in accordance with the technical conditions for the performance of conversion maps, in the area of the city of Lodz. A detailed analysis was made for the registration of objects, which are plots surveying. An analysis of changes in the area of plots for selected surveying districts, which brought the introduction of the coordinate system "2000." It was found that on 883 plots there was a growth area and on 115 plots of land the area decreased. These changes were introduced into the Register of Land, Buildings and Premises conducted for the city of Lodz analyzed for surveying districts.

This is the first article which includes an analysis of the changes of the city of Lodz resulting from the change of coordinate systems. The analysis shows that the size of the city increased. An introduction of rectangular coordinate system "2000" for the city of Lodz resulted in unification of the performed geodetic surveys.

Keywords: coordinate systems, transformation, land, area

Przestano do redakcji: 30.08 .2016 r.

Przyjęto do druku: 15.09.2016 r.

DOI: $10.7862 / \mathrm{rb} .2016 .141$ 
